\title{
Response of porcine oocytes exposed to testosterone and substance $P$ in vitro
}

\author{
DAWID WINIARCZYK*,**, RYSZARD BOBOWIEC**, URSZULA KOSIOR-KORZECKA**, \\ KATARZYNA WITKOWSKA**, PAULINA RADWAŃSKA**
*Department of Experimental Embryology, Institute of Genetics and Animal Breeding, Polish Academy of Sciences, Postepu 36A, Jastrzębiec, 05-552 Magdalenka, Poland
**Department of Pathophysiology, Chair of Preclinical Veterinary Sciences, Faculty of Veterinary Medicine, University of Life Sciences in Lublin, Akademicka 12, 20-033, Lublin, Poland

Winiarczyk D., Bobowiec R., Kosior-Korzecka U., Witkowska K., Radwańska P. Response of porcine oocytes exposed to testosterone and substance $P$ in vitro

\section{Summary}

The overproduction of androgens during the course of foliculogenesis may lead to disturbances in ovulation the main reason for the establishment of the pathological state known as polycystic ovarian syndrome (PCOS). Furthermore, recently attention has been drawn to the involvement of tachykinins such as substance $P(S P)$ in this process. Apart from this, both in animals and women, the above factors may impair oocyte development. Taking into account the aforementioned data we sought to find and compare the response of isolated porcine oocytes to different doses of testosterone (T) and SP with the goal of clarifying their effect on oocyte growth and meiosis progress. In our experimental approach porcine oocytes were exposed to these factors for $4 \mathrm{~h}, 20 \mathrm{~h}$ or $44 \mathrm{~h}$ of culture. The obtained results reveal that both $\mathrm{T}$ and SP inhibit growth of porcine oocytes, cumulus cell expansion and meiotic resumption in vitro. Our data show that the inhibitory effect of SP on porcine oocytes is far weaker than the impact of $T$.

Keywords: oocyte growth, meiotic resumption, testosterone, substance $P$

A dynamic interplay between the oocytes and the surrounding environment determines the achievement of maturation by incompetent porcine oocytes (15). This balance might be impaired in the course of polycystic ovary syndrome (PCOS). Such complex endocrine disorder occurring in women and female domestic animals leads to anovulation and, eventually, to infertility (8). One of the known etiological factors and hallmarks of PCOS is a high level of androgens, mainly testosterone $(\mathrm{T})$, both in follicular fluid and blood plasma (7). These steroids exert an effect on oocytes through the non-classical steroid receptor signalling in pathways that presumably refer also to oocyte growth and maturation (14). Consequently, the impairment of a delicate balance within the microenvironment of the ovarian follicle, disrupting the activity of theca and granulosa cells, causes disturbances or suspension of oocyte growth and development. However, when ovulation occurs, the oocyte is of a very poor quality that leads to the reduced frequency of fertilization and subsequent implantation as well as increases the risk of miscarriage (27).
In recent years tachykinins, to which substance P (SP) belongs, appear as bioactive peptides also expressed in ovarian tissues. SP and other tachykinins were found in the follicular fluid and their receptors were detected in oocytes $(16,23,26)$. Substance $\mathrm{P}$ is a peptide (10-11 amino acids in length) which exerts most of its biological effects through a specific receptor termed NK-R. The activation of NK-R has been implicated in a wide variety of biological actions, including the stimulation of endocrine glands (1). Currently, it is well known that SP is produced and released not only from neurons of the central nervous system (CNS), where it is regarded as a neurotransmitter, but also by non-neuronal cells such as immune and inflammatory cells $(1,24)$. Apart from a well known action of SP on the modulation of pain perception and smooth muscle motility, including uterotonic actions, regulation of emotional behaviour, induction of neurogenic inflammation, some authors draw attention to the implication of this peptide in the ovarian function (5). Furthermore, tachykinins, including SP, have been found in the ovary and remain under suppressive effects of gonadotropins 
(6). The presence of tachykinins has been shown in different ovarian structures such as nerve fibers, blood vessels as well as granulose, luteal and interstitial cells, where they likely exert a paracrine modulatory action (5). The results obtained by Brylla et al. confirm that lack of tachykinin receptors in follicular structure is responsible for the disturbance of oocyte expulsion and consequently may lead to infertility (4). According to these data, it can be assumed that tachykinins, especially SP, may be potential modulators of oocyte growth and maturation via the interaction with various classes of receptors (NK-R1, NK-R2, and NK-R3). To our knowledge until now no attempt has been undertaken to reveal SP effects on oocyte growth and maturation.

Taking into account the aforementioned data and the statement that ovulation is regarded as an inflammatory process, we sought to find if this tachykinin also exerts an effect on porcine oocytes.

Therefore the aim of this study was to estimate and compare the relatively known inhibitory effects of $\mathrm{T}$ with the unknown, although expected, effects of SP on porcine oocyte growth, cumulus cell expansion and meiotic resumption.

\section{Material and methods}

Source of oocytes. Ovaries were collected from six-eight-month old gilts (Polish Large White, body mass: 80-120 $\mathrm{kg}$ ) at a local slaughterhouse. They were transported to the laboratory in $0.9 \%$ saline at room temperature within $1 \mathrm{~h}$. The experimental procedure was approved by the Second Local Ethics Committee for Animal Experimentation in Lublin (License No. 72/2014).

Oocyte collection and culture. The ovaries were washed three times in PBS containing $50 \mu \mathrm{g} / \mathrm{ml}$ of gentamicin and placed on a Petri dish heated to $37^{\circ} \mathrm{C}$ and filled with TCM-199 culture medium and $60 \mu 1$ heparin. Cumulus oocyte complexes (COCs) were obtained by aspiration of $2-5 \mathrm{~mm}$ follicles using a syringe fitted with an 18-gauge needle and selected under a stereomicroscope (ZOOM, MSZ 200). Next the oocytes were classified following the criteria described by Marquant-Le Guienne (13) according to the cumulus oophorus morphology, corona radiata and the cytoplasmic aspect. Only the COCs with a homogenous cytoplasm and a complete cumulus oophorus (Grade 1) were chosen for the study. COCs classified as Grade 2-4 were excluded. Grade 1 oocytes were washed three times in phosphate-buffered saline (PBS) modified by the addition of $36 \mathrm{mg} / \mathrm{l}$ of puryvate (Sigma Chemicals Co., St. Louis, MO, USA), 1000 $\mathrm{mg} / \mathrm{l}$ of D-glucose (Sigma Chemicals Co., St. Louis, MO, USA), $0.5 \mathrm{~g} / 1$ of bovine serum albumin (BSA, Fraction V, Sigma Chemicals Co., St. Louis, MO, USA) and $50 \mu \mathrm{g} / \mathrm{ml}$ of gentamicin (Sigma Chemicals Co., St. Louis, MO, USA), and transferred to the culture medium. The oocytes were cultured in a medium containing 1.06 g of TCM-199 (with Hanks' salts; Sigma Chemicals Co., St. Louis, MO, USA), $0.5 \mathrm{ml}$ of amino acids mixture (Sigma Chemicals Co., St. Louis, MO, USA), $0.5 \mathrm{~g}$ of glucose; $3 \mathrm{~g}$ of BSA, $125 \mu \mathrm{l}$ of gentamicin $(10 \mathrm{mg} / \mathrm{ml})$ and distilled water to $100 \mathrm{ml}$. Fifty oocytes were cultured in $4 \mathrm{ml}$ of the medium in six-well multidishes (Nunclon, Danmark). COCs were incubated at $37^{\circ} \mathrm{C}$ in a sterile atmosphere of humidified air containing $5 \% \mathrm{CO}_{2}(3,11,29)$.

The COCs were randomly assigned to control and experimental groups. The control oocytes $(n=150)$ were cultured for $44 \mathrm{~h}$ without $\mathrm{T}$ and SP. T and SP were tested at two supraphysiological, relative to normal follicular fluid, concentrations: 0.5 or $2.5 \mu \mathrm{M}$ and 0.5 or $1 \mathrm{nM}$, respectively. COCs were exposed to the aforementioned factors for $4 \mathrm{~h}$ and $20 \mathrm{~h}$, respectively (after that time the media were replaced with T and SP free media) or permanently, during the entire $44 \mathrm{~h}$ of culture. To analyze the response to above-mentioned factors, the oocytes were divided into the following experimental groups subjected to different doses and times of exposition to T or SP, respectively:

I. COCs exposed to $0.5 \mu \mathrm{M}$ of $\mathrm{T}$ for $4 \mathrm{~h}(\mathrm{n}=150)$;

II. COCs exposed to $0.5 \mu \mathrm{M}$ of $\mathrm{T}$ for $20 \mathrm{~h}(\mathrm{n}=150)$;

III. COCs exposed to $0.5 \mu \mathrm{M}$ of $\mathrm{T}$ for $44 \mathrm{~h}(\mathrm{n}=150)$;

IV. COCs exposed to $2.5 \mu \mathrm{M}$ of $\mathrm{T}$ for $4 \mathrm{~h}(\mathrm{n}=150)$;

V. COCs exposed to $2.5 \mu \mathrm{M}$ of $\mathrm{T}$ for $20 \mathrm{~h}(\mathrm{n}=150)$;

VI. COCs exposed to $2.5 \mu \mathrm{M}$ of $\mathrm{T}$ for $44 \mathrm{~h}(\mathrm{n}=150)$;

VII. COCs exposed to $0.5 \mathrm{nM}$ of SP for $4 \mathrm{~h}(\mathrm{n}=150)$;

VIII. COCs exposed to $0.5 \mathrm{nM}$ of SP for $20 \mathrm{~h}(\mathrm{n}=150)$;

IX. COCs exposed to $0.5 \mathrm{nM}$ of SP for $44 \mathrm{~h}(\mathrm{n}=150)$;

X. COCs exposed to $1 \mathrm{nM}$ of SP for $4 \mathrm{~h}(\mathrm{n}=150)$;

XI. COCs exposed to $1 \mathrm{nM}$ of SP for $20 \mathrm{~h}(\mathrm{n}=150)$;

XII. COCs exposed to $1 \mathrm{nM}$ of SP for $44 \mathrm{~h}(\mathrm{n}=150)$.

After $44 \mathrm{~h}$ of experiment, in all groups the brilliant cresyl blue $(\mathrm{BCB})$ test and the orcein test were performed. The measurement of granulosa cell expansion, regardless of the time of the COCs exposure to T or SP, was carried out after $20 \mathrm{~h}$ and $44 \mathrm{~h}$ of experiment.

Brilliant cresyl blue test. The test was used to determine the growth of oocytes (22). It is based on glucose-6-phosphate dehydrogenase (G6PDH) activity during oocyte development. It is dependent on the capability of G6PDH to convert the dye from blue to a colourless state. Due to sufficient concentration of the enzyme in oocytes undergoing growth, the dye is reduced to being colourless, while fully-grown oocytes remain blue due to the low amount of cytoplasmic G6PDH activity (2).

In the present study, the cultured COCs were washed with PBS after $4 \mathrm{~h}, 20 \mathrm{~h}$ and $44 \mathrm{~h}$ of experiment, respectively. Then, oocytes were exposed to $26 \mu \mathrm{M}$ BCB solution in PBS for $1 \mathrm{~h}$ at $37^{\circ} \mathrm{C}$ in humidified air containing $5 \% \mathrm{CO}_{2}$. Following BCB staining, the oocytes were washed three times with PBS. After washing, COCs were observed under stereomicroscope and classified into two groups, depending on their cytoplasm coloration. The oocytes with blue colour of cytoplasm were categorized into $\mathrm{BCB}+$ and recognized as fully-grown whereas the cells with the colourless cytoplasm were considered as $\mathrm{BCB}-$ and recognized as undergoing growth.

Orcein test - determination of $\mathrm{T}$ and $\mathrm{SP}$ effect on meiotic resumption. The oocytes removed from the culture were denuded by incubating in a medium containing $500 \mathrm{IU} / \mathrm{ml}$ hyaluronidase enzyme for $10 \mathrm{~min}$ followed by repeated pipetting. Completely denuded oocytes were transferred to glass slides in small drops of $3 \mu 1$ medium and fixed in methanol: acetic acid $(3: 1)$ for $24 \mathrm{~h}$. Next, the cells were stained with $1 \%$ aceto-orcein and examined under a phase- 
contrast microscope at $400 \times$ magnification. Oocytes were classified as GV stage if nuclear membrane was present and the chromatin was uncondensed (9).

Measurement of cumulus cell expansion intensity under the influence of $\mathbf{T}$ or SP. The COCs exposed for 4, 20 or $44 \mathrm{~h}$ to T or SP were photographed and measured using the Scion Image programme under a phase-contrast microscope at $100 \times$ magnification. Mean diameters of compact granulosa cells were measured and then the same COCs were compared with each other at specified intervals. The control diameter values of COCs represents mean diameter values obtained during the culture without addition of the tested substances. Finally, we calculated the percentage change of COCs diameter after $20 \mathrm{~h}$ and $44 \mathrm{~h}$ under the influence of different concentrations of T and SP compared to the initial diameter of COCs $(17,18)$.

Statistical analysis. Statistical analysis of the obtained results was performed using Statistica 10. The results were presented as mean \pm standard deviation. The results using Student's t test at $\mathrm{P} \leq 0.05$.

\section{Results and discussion}

Effect of T and SP on the growth of oocytes. The obtained results indicate that $\mathrm{T}$ is an inhibitor of the oocyte growth. BCB staining showed a significantly higher number of cells undergoing growth after incubation with T compared to the control group. Already $4 \mathrm{~h}$ after the incubation of oocytes with $\mathrm{T}$ at pathological concentration $(2.5 \mu \mathrm{M})$, significantly $(\mathrm{P} \leq 0.05)$ more still growing cells were visible. In each of the experimental groups, a marked increase in the number of cells undergoing growth compared to the control group was found. The lowest number of cells undergoing growth were observed after 4 hours of exposure to a lower concentration of testosterone $(0.5 \mu \mathrm{M})$, while after $44 \mathrm{~h}$ incubation in the environment of the highest concentration of this hormone $(2.5 \mu \mathrm{M})$, the growth of oocytes was the most significantly suppressed (Fig. 1). This may be due to the inhibition of the expression of some proteins required for oocyte growth, for example the

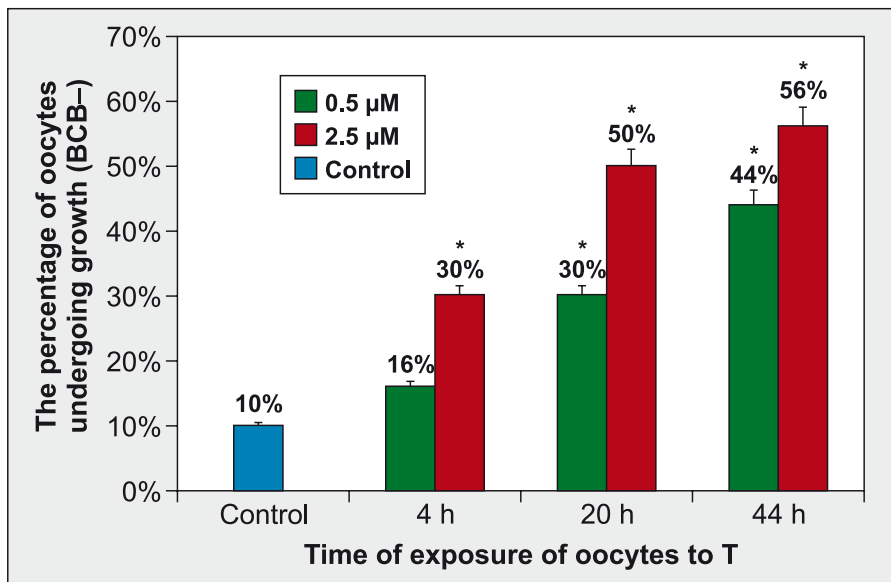

Fig. 1. The percentage of porcine oocytes undergoing growth (BCB-) under the influence of different doses and different times of exposure to testosterone ( $\mathrm{T}$ ) in vitro (BCB test) (mean $\pm \mathrm{SD} ; \mathbf{n}=\mathbf{5 0}$ )

Explanation: $* \mathrm{P} \leq 0.05$ compared to control differentiating growth factor (GDF-9). Other authors $(9,27)$ have shown that in the case of women who suffer from PCOS resulting from hyperandrogenism, the expression of this protein is reduced.

For a proper growth and cytoplasmic oocyte maturation, it is also necessary to correct the oscillation of $\mathrm{Ca}^{2+}$. An appropriate $\mathrm{Ca}^{2+}$ level is necessary during the cortical reaction, the cortical connections of oolemma and the activation of the oocyte (22). In other studies authors have shown that $\mathrm{T}$ reduces the intracellular $\mathrm{Ca}^{2+}$ stores. As a result, proper growth and maturation of the oocyte cytoplasm cannot occur. The reason for this is the antagonistic effect of testosterone on 17 - $\beta$-estradiol (28).

There are no available reports on the effects of SP on oocyte growth. Our examination of the growth of oocytes exposed to SP did not present uniform responses. Under the influence of a lower concentration of SP $(0.5 \mathrm{nM})$ and the shortest time of exposure, the oocytes did not show any suppression of growth compared to the control group. At the same time, in the group exposed to a higher concentration of SP (1 nM), a slight increase in suppression of cell growth was observed compared to the control group. In other groups the number of cells undergoing growth was significantly higher $(\mathrm{P} \leq 0.05)$. Similarly to $\mathrm{T}$, $\mathrm{SP}$ also induced a suppressive effect on the growth of oocytes. However, this tachykinin inhibited oocyte growth to a considerably lesser extent than testosterone (Fig. 2). The molecular mechanisms responsible for the reduction of the degree of growth of oocytes exposed to substance P remain unknown. They may be related to the modulation of steroid hormone secretion by granulosa cells under the influence of SP, but the results of other authors are equivocal (5).

Influence of T and SP on resumption of oocyte meiosis. When oocyte nuclear maturity is achieved, the oocyte passes from the germinal vesicle $(\mathrm{GV})$ stage to metaphase II (M II). This process is dependent on the

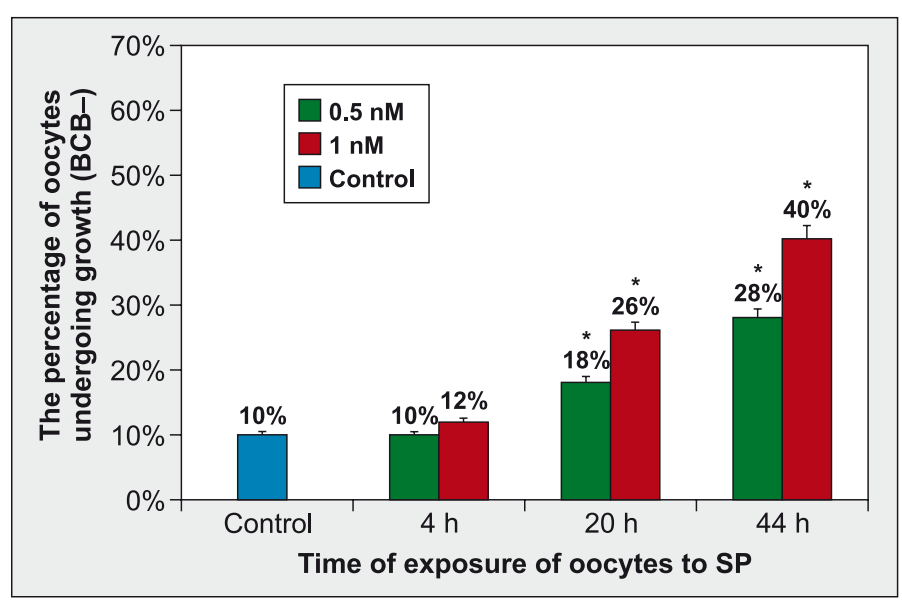

Fig. 2. The percentage of porcine oocytes undergoing growth (BCB-) under the influence of different doses and different times of exposure to substance $\mathrm{P}(\mathrm{SP})$ in vitro (BCB test) (mean $\pm \mathrm{SD} ; \mathbf{n}=\mathbf{5 0}$ )

Explanation: as in Fig 1. 


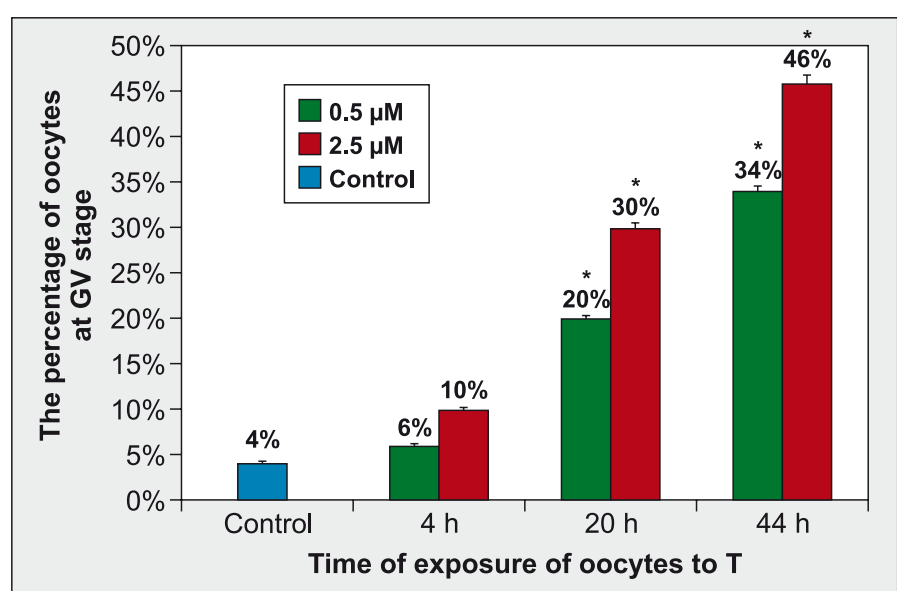

Fig. 3. The effect of testosterone $(T)$ on the percentage of porcine oocytes at the $G V$ stage in vitro (mean $\pm S D ; n=50)$ Explanation: as in Fig 1.

maturity of the oocyte cytoplasm. During its growth, proteins are synthesized and ribonucleoproteins are stored. These proteins will later participate in the resumption of meiosis. Moreover, it is dependent on transcriptional silencing and destroying the transcripts responsible for withholding division, energy production, protein synthesis and cell metabolism. Only a meiotically mature oocyte can be fertilized $(21,22)$.

One of the transcription factors involved in the meiotic resumption and further maturation of the oocyte is the nuclear androgen receptor (AR). Studies by other authors have shown that this protein is located in the theca cells, granulosa cells and the oocyte $(12,20)$. AR is a mobile protein which can be found in the nucleus and cytoplasm. It is responsible for the physiological response to androgens. One of the most potent ligands affecting this receptor is testosterone. T binds to the receptor and this complex attaches to the DNA affecting the expression of specific genes (10).

It has also been observed that most of the mRNA transcripts and AR proteins occur in immature oocytes. Other authors have reported that there are abnormalities in the transcription of certain genes in oocytes obtained from women with PCOS $(7,27)$. It has been shown that $\mathrm{T}$ has an effect on the expression of proteins from the family of transforming growth factor beta (TGF- $\beta$ ), for example there is a lower level of GDF-9 transcript in oocytes isolated from women with PCOS (27).

The results of this study show that $\mathrm{T}$ affects meiotic resumption in oocytes (Fig. 3). It has been shown that $\mathrm{T}$ inhibits this process (in the group with the higher concentration and the longest incubation time $46 \%$ of oocytes were at GV stage), which is in accordance with other studies $(25,28)$. However, there are also reports showing the stimulating effect of $\mathrm{T}$ on the resumption of meiosis $(12,14)$. Interruption of the nuclear maturation of oocytes by $\mathrm{T}$ may be caused by disturbances in the growth, cytoplasmic maturation and the gene expression profile.

As in the case of growth, no literature reports on the effects of SP on meiotic resumption of oocytes

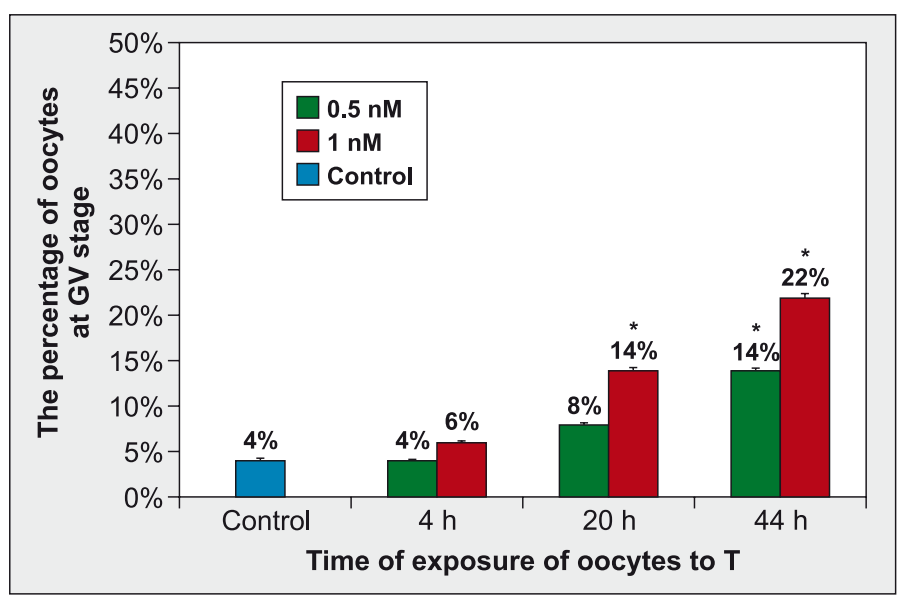

Fig. 4. The effect of substance $P$ (SP) on the percentage of porcine oocytes at the GV stage in vitro (mean $\pm S D ; n=50)$. Explanation: as in Fig 1.

have been found. The results of this study show that it has an impact on this process. However, it is considerably weaker than the effect of $\mathrm{T}$. In the group of oocytes exposed to the higher concentration and the longest incubation time ( $44 \mathrm{~h}), 22 \%$ of oocytes were GV (Fig. 4). Molecular mechanisms responsible for the inhibition of oocyte meiosis by SP are unknown.

Effect of T and SP on cumulus cell expansion. Measurement of the percentage of change in the diameter of the COCs showed that both testosterone and substance $\mathrm{P}$ exert a significant $(\mathrm{P} \leq 0.05)$ inhibitory influence on granulose cells expansion as compared with the control group. Even during the shortest period of incubation ( $4 \mathrm{~h}$ ) with $\mathrm{T}$ the differences were significant. T was a potent inhibitor of cumulus cell expansion at any incubation time period (Tab. 1). Females with PCOS have rare or no ovulation. This is caused by several factors. The first of them is the previously mentioned lack of GDF-9 caused by testosterone. This results in insufficient production of the matrix, due to which granulosa cells undergo expansion to a smaller extent $(19,27)$.

The results of this study show that $\mathrm{T}$ significantly suppresses the expansion of the granulosa cells. This finding is in accordance with the data obtained by other authors (25).

SP also affects the expansion of the granulosa cells. There are no other reports in the literature concerning this issue. Molecular mechanisms responsible for this process are unknown.

To sum up, apart from suppressive effects of testosterone, substance $\mathrm{P}$ as a member of tachykinin family can also diminish the growth, cumulus cell expansion and meiotic resumption of porcine oocytes in vitro. Meanwhile, our data show that the inhibitory influence of SP on porcine oocytes is far weaker than the impact of $\mathrm{T}$.

Considering the above, the supraphysiological levels of testosterone and substance $\mathrm{P}$ in the follicular fluid may be used in the future as potential markers of growth and maturation disorders of porcine oocytes. 
Tab. 1. The percentage changes of COCs diameter under the influence of different concentrations and times of exposure to $T$ or SP compared to the initial diameter of COCs $($ mean $\pm S D ; n=50)$

\begin{tabular}{|c|c|c|c|c|c|c|}
\hline \multirow{2}{*}{$\begin{array}{l}\text { Duration } \\
\text { of incubation } \\
\text { with factor }\end{array}$} & \multirow{2}{*}{$\begin{array}{c}\text { The } \\
\text { measurement } \\
\text { time }\end{array}$} & \multicolumn{2}{|c|}{ Testosterone } & \multicolumn{2}{|c|}{ Substance P } & \multirow{2}{*}{ Control } \\
\hline & & $0.5 \mu \mathrm{M}$ & $2.5 \mu \mathrm{M}$ & $0.5 \mathrm{nM}$ & $1 \mathrm{nM}$ & \\
\hline \multirow{2}{*}{$4 \mathrm{~h}$} & $20 \mathrm{~h}$ & $4.58 \%{ }^{*}( \pm 2.26 \%)$ & $3.15 \% *( \pm 1.03 \%)$ & $4.71 \%{ }^{*}( \pm 1.00 \%)$ & $4.95 \%{ }^{*}( \pm 1.52 \%)$ & \multirow{2}{*}{$7.91 \%( \pm 1.42 \%)$} \\
\hline & $44 \mathrm{~h}$ & $6.04 \%{ }^{*}( \pm 1.37 \%)$ & $4.69 \%{ }^{*}( \pm 1.94 \%)$ & $7.91 \%{ }^{*}( \pm 1.42 \%)$ & $7.28 \%{ }^{*}( \pm 1.73 \%)$ & \\
\hline \multirow{2}{*}{$20 \mathrm{~h}$} & $20 \mathrm{~h}$ & $2.16 \%{ }^{*}( \pm 1.12 \%)$ & $1.98 \% *( \pm 0.50 \%)$ & $3.84 \% *( \pm 0.50 \%)$ & $3.23 \% *( \pm 0.80 \%)$ & \multirow{2}{*}{$13.82 \%( \pm 0.90 \%)$} \\
\hline & $44 \mathrm{~h}$ & $3.36 \% *( \pm 1.81 \%)$ & $3.03 \% *( \pm 0.70 \%)$ & $6.51 \%{ }^{*}( \pm 1.11 \%)$ & $5.60 \% *( \pm 0.70 \%)$ & \\
\hline \multirow{2}{*}{$44 \mathrm{~h}$} & $20 \mathrm{~h}$ & $2.06 \% *( \pm 0.60 \%)$ & $1.72 \%{ }^{*}( \pm 0.80 \%)$ & $3.76 \%{ }^{*}( \pm 1.00 \%)$ & $3.43 \% *( \pm 0.70 \%)$ & \multirow{2}{*}{$16.46 \%( \pm 1.47 \%)$} \\
\hline & $44 \mathrm{~h}$ & $2.53 \%{ }^{*}( \pm 1.22 \%)$ & $2.62 \% *( \pm 0.50 \%)$ & $6.06 \% *( \pm 1.15 \%)$ & $4.89 \% *( \pm 0.80 \%)$ & \\
\hline
\end{tabular}

Explanations: The control COCs were cultured for $44 \mathrm{~h}$ without $\mathrm{T}$ and SP. T and SP in experimental cultures were tested at two concentrations: 0.5 or $2.5 \mu \mathrm{M}$ and 0.5 or $1 \mathrm{nM}$, respectively. COCs were exposed to the aforementioned factors for $4 \mathrm{~h}$ and $20 \mathrm{~h}$, respectively (after that time the media were replaced with T and SP free media) or permanently, during the entire $44 \mathrm{~h}$ of culture. The measurements were carried out after 20 or $44 \mathrm{~h}$ of experiment. $* \mathrm{P} \leq 0.05$ compared to control.

\section{References}

1. Adamus M.: Wpływ substancji P na komórki krwi. Postepy Hig. Med. Dośw. 2009, 63, 106-113.

2. Beall S., Brenner C., Segars J.: Oocyte maturation failure: a syndrome of bed eggs. Fertil. Steril. 2010, 94, 2507-2513.

3. Borzym E., Bobowiec R., Kosior-Korzecka U., Martelli F., Burmańczuk A.: Disturbances of cow oocyte maturation by phytoestrogens. Med. Weter. 2008, 64, 1107-1111.

4. Brylla E., Aust G., Geyer M., Uckermann O., Löffler S., Spanel-Borowski K.: Coexpression of preprotachykinin A and B transcripts in the bovine corpus luteum and evidence for functional neurokinin receptor activity in luteal endothelial cells and ovarian macrophages. Regul. Pept. 2005, 125, 125-133.

5. Debeljuk L.: Tachykinins and ovarian function in mammals. Peptides 2006, 27, 736-742.

6. Debeljuk L.: Tachykinins in the normal and gonadotropin-stimulated ovary of the mouse. Peptides 2003, 24, 1445-1448.

7. Dumesic D., Abbott D.: Implications of polycystic ovary syndrome (PCOS) on oocyte development. Semin. Reprod. Med. 2008, 26, 53-56.

8. Dumesic D., Padmanabhan V., Abbott D.: Polycystic ovary syndrome and oocyte developmental competence. Obstet. Gynaecol. Surv. 2008, 63, 69-48.

9. Fouladi-Nashta A. A., Waddington D., Campbell K. H. S.: Maintenance of bovine oocytes in meiotic arrest and subsequent development in vitro: A comparative evaluation of antral follicle culture with other methods. Biol. Reprod. 1998, 59, 255-262.

10. Gelmann E. P.: Molecular biology of the androgen receptor. J. Clin. Oncol 2002, 20, 3001-3015.

11. Gilchrist R. B., Thompson J. G.: Oocyte maturation: Emerging concept and technologies to improve developmental potential in vitro. Theriogenology 2007, 67, 6-15.

12. Gleicher N., Weghofer A., Barad D.: The role of androgens in follicle maturation and ovulation induction: friend or foe of infertility treatment? Reprod. Biol. Endocrinol. 2011, 9, 116-127.

13. Guienne M. L.: Atlas of the bovine and porcine oocyte. AETE Newsletter $1999,10,6-8$

14. Hammers S.: Steroids and oocyte maturation - a new look at an old story. Mol. Endocrinol. 2004, 18, 769-775.

15. Hickey T. E., Marrocco D. L., Amato F., Ritter L. J., Norman R. J., Gilchrist R. B., Armstrong D. T.: Androgens augment the mitogenic effects of oocytesecreted factors and growth differentiation factor 9 on porcine granulosa cells. Biol. Reprod. 2005, 73, 825-832.

16. Jarry H., Meyer B., Holzapfel G., Hinney B., Kuhn W., Wuttke W.: Angiotensin II/III and substance P in human follicular fluid obtained during IVF: relation of the peptide content with follicular size. Acta Endocrinol. 1988, 119, 277-282.

17. Ju S., Rui R.: Effects of cumulus cells on in vitro maturation of oocytes and development of cloned embryos in the pig. Reprod. Domest. Anim. 2012, 47, 521-529.

18. Karja N.W. K.: Nuclear maturation of porcine oocytes in vitro: effect of the cumulus-oocyte complexes quality. Indones. J. Biotechnol. 2008, 13, 1078 $-1084$

19. Kotlarska K.: Ekspansja komórek ziarnistych wzgórka jajonośnego - proces niezbędny do prawidłowego przebiegu owulacji i zapłodnienia. Postepy Biol. Komórki 2009, 36, 171-187.
20. Lenie S., Smitz J.: Functional AR signalling is evident in an in vitro mouse follicle culture bioassay that encompasses most stages of folliculogenesis. Biol. Reprod. 2009, 80, 685-695.

21. Moor R. M., Dai Y., Lee C., Fulka J. Jr.: Oocyte maturation and embryonic failure. Hum. Reprod. 1998, 4, 223-236.

22. Opiela J., Kątska-Książkiewicz L.: Charakterystyka zdolności rozwojowej oocytów ssaków w aspekcie zapłodnienia i rozwoju zarodkowego. Cz. II. Regulacja dojrzałości cytoplazmatycznej i genomowej. Biotechnologia 2005, 2, 151-162.

23. Page N. M.: New challenges in the study of the mammalian tachykinins Peptides 2005, 26, 1356-1368.

24. Patacchini R., Lecci A., Holzer P., Maggi C. A.: Newly discovered tachykinins raise new questions about their peripheral roles and the tachykinin nomenclature. Trends Pharmacol. Sci. 2004, 25, 1-3.

25. Petr J., Tepla O., Rozinek J., Jilek F.: Effect of testosterone and dibutyryl c-AMP on the meiotic competence in pig oocytes of various size categories. Theriogenology 1996, 46, 97-108.

26. Pintado O., Pinto F. M., Pennefather J. N., Hidalgo A., Baamonde A., Sanchez T., Candenans $M$. L.: A role for tachykinins in female mouse and rat reproductive function. Biol. Reprod. 2003, 69, 940-946.

27. Qiao J., Feng H. L.: Extra- and intra-ovarian factors in polycystic ovary syndrome: impact on oocyte maturation and embryo developmental competence. Hum. Reprod. 2011, 17, 17-33.

28. Tesarik J., Mendoza C.: Nongenomic effects of 17 beta-estradiol on maturing human oocytes: relationship to oocyte developmental potential. J. Clin. Endocrinol. Metab. 1995, 80, 1438-1443.

29. Wehrend A., Meinecke B.: Kinetic of meiotic progression, M-phase promotic factor (MPF) and mitogen-activated protein kinase (MAP kinase) activities during in vitro maturation of porcine and bovine oocytes: species specific differences in the length of the meiotic stages. Anim. Reprod. Sci. 2001, 66, $175-184$

Corresponding author: prof. dr hab. Ryszard Bobowiec, Akademicka 12, 20-033 Lublin, Poland; e-mail: ryszard.bobowiec@up.lublin.pl 